\title{
огляд
}

\section{INFUSION THERAPY IN THE PERIOPERATIVE PERIOD IN DOGS AND CATS}

\author{
P. K. SOLONIN, Candidate of Veterinary Sciences, Associate Professor, \\ Department of Surgery and Pathophysiology \\ named after Academician I. O. Povazhenko \\ https://orcid.org/0000-0003-0119-6490
}

National University of Life and Environmental Sciences of Ukraine, Kyiv, Ukraine

M. A. KULIDA, Candidate of Veterinary Sciences, Associate Professor,

Department of Surgery and Pathophysiology

named after Academician I. O. Povazhenko

https://orcid.org/0000-0001-8937-1972

National University of Life and Environmental Sciences of Ukraine, Kyiv, Ukraine

E-mail: mkulida@ukr.net

Abstract.The modern approach to the treatment of animals with surgical pathology requires the application of infusion solutions throughout the whole perioperative period: before the surgery (in case of emergency treatment), during the surgery, and after it.

In animals with surgical diseases that come for treatment, there are quite often varying degrees of water-electrolyte balance disorder. The cause of these disorders is both surgical pathology itself (for example, peritonitis, bowel obstruction), and concomitant pathology present in the patient (renal failure, diabetes mellitus, cardiac deficiencies, etc.). The success of surgery treatment largely depends on the proper assessment and correction of these disorders.

This article presents modern approaches to the issues on infusion therapy in veterinary surgery of dogs and cats.

Great attention is paid to the selection of means for infusion therapy in animals in the perioperative period. The article contains examples of determining the volume of solutions for infusion during the preoperative preparation, intensive therapy for massive intraoperative blood loss, and postoperative management of patients.

Keywords: perioperative period, infusion therapy, blood loss, crystalloids, colloids, infusion solutions 


\section{Introduction}

The modern approach to the treatment of animals with surgical pathology requires the application of infusion solutions throughout the perioperative period: before surgery (in case of acute interventions), during surgery, and after surgery (Battaglia \& Steele, 2021).

In animals with surgical diseases that come for treatment, a varying degree of water-electrolyte balance (WEB) disorder is often observed. The cause of these disorders is both surgical pathology itself (for example, peritonitis, bowel obstruction), and concomitant pathology present in the patient (renal failure, diabetes mellitus, cardiac deficiencies, etc.). The success of the surgical treatment depends on the proper assessment and correction of these disorders (Belyayev et al., 2004).

The purpose of the study was to investigate modern approaches to the issues on infusion therapy in veterinary surgery of dogs and cats.

\section{Materials and methods of research}

The material of the research was modern publications that describe the issues of infusion therapy in veterinary surgery of dogs and cats, which is very important in the practical training of veterinary medicine practitioners. The methodological basis of the study is an investigative approach, dialectically combined with the principles of systematicity. Chronological, systematic, and analytical methods were used in the research process.

\section{Results of the research and their discussion}

\section{Preoperative infusion therapy.}

The scope and tasks of preoperative infusion preparation depend on many fac- tors and often differ significantly in preparation for planned and urgent surgery.

Planned surgical interventions. When preparing the animals for planned surgical treatment, it is necessary first of all to compensate for the existing violations of hemoconcentration indices. Thus, it is recommended in most clinical cases that before the planned surgery, the hemoglobin level should be within the range of 110-180 g/L for dogs and 80-150 g/L for cats, hematocrit level - at least $37 \%$ for dogs and $26 \%$ for cats, and albumin level - at least $25 \mathrm{~g} / \mathrm{L}$ for dogs and cats. Maintenance of such indicators creates optimal conditions for healing of postoperative wounds, recovery of functions, as well as protection against the development of dangerous anemia as a result of possible development of intraoperative blood loss (Cherniy et al., 2012).

Three variants of infusion therapy are possible in preparation for planned surgery depending on the patient's category:

The first category of patients healthy or sick animals that do not require infusion therapy. This applies to patients who do not have significant health impairments, which are planned for surgical procedures with small duration and injures (castrations, amputations of stubby fingers, extractions of milk teeth). As a rule, these patients do not have signs of dehydration and WEB disorders, and after the surgery, they quickly start taking water. Thus, WEB disorders do not develop in these animals, and, therefore, infusion therapy in the perioperative period is not required;

The second category of patients animals with chronic disorders of water-electrolyte metabolism that require appropriate treatment. Most often these disorders are caused by a deficiency of one or several ions. For example, the hypokalemic and hypochloremic alkalosis is formed during pyloroduodenal steno- 
sis, which requires clear determination of potassium and chlorine deficiency and its appropriate correction (Table 1);

The third category of patients - those who develop severe WEB disorders before the planned surgery or are first diagnosed with a new concomitant disease during the examination, at which dangerous WEB disorders are possible. Examples of such disorders can be firstly detected signs of cardiovascular deficiency, renal deficiency, and diabetes mellitus (Butrov \& Galenko, 2008; Ko, 2019).

In a large number of cases, latent diseases are detected accidentally during the screening examination of patients before surgical treatment. In this case, it is recommended to postpone planned operative treatment for further follow-up examination of the patient, to ensure compensation for the detected disease and to determine the risk degree (Shlapak et al., 2013).

Urgent surgical interventions. Most often these interventions are performed due to urgent surgeries on abdominal cavity organs, traumas. Infusion therapy in these situations should be focused on the support of adequate hemodynamics, preloading, and cardiac output (Detyu, 2009).

It should be remembered that preoperative preparation significantly reduces the risk of complications and mortality in sick animals with signs of "acute abdomen". The disadvantages of infusion therapy in such patients may not have a significant effect on the course of the surgery itself but will certainly be fully manifested after it. The consequences of poor preoperative infusion preparation in such patients are varying degrees of damage to the kidneys, lungs, liver, which might be completely avoided (Galushko, 2011).

The modern standards for preoperative preparation of sick animals with urgent surgical pathology include the following actions:

- catheterization of two veins;

- catheterization of the urinary bladder;

- infusion therapy with crystalloid and colloidal solutions in the appropriate volumes.

It is important to note that infusion preparation of the patient for surgery should be started with the introduction of crystalloids. Under no circumstances can infusion therapy be started with the introduction of colloids. First of all, it is necessary to carry out the rehydration of the body. If the sick animal has water deficiency - it should first of all be given water, i.e. crystalloidal solutions. If you start the infusion of colloids, the patient is

\section{Pathologic conditions, losses of electrolytes and their replenishment (Hilberi, 1989)}

\begin{tabular}{|l|c|c|}
\hline \multicolumn{1}{|c|}{ Condition } & Losses & Replenishment \\
\hline Gastric vomiting & $\mathrm{K}+, \mathrm{H}+, \mathrm{Cl}^{-}, \mathrm{Na}+, \mathrm{H}_{2} \mathrm{O}$ & $\begin{array}{c}\text { Sol. 0.9\% } \mathrm{NaCl}+\mathrm{KCl} \mathrm{10-20} \\
\mathrm{mmol} / \mathrm{L}\end{array}$ \\
\hline Duodenal vomiting & Mixed losses & Hartmann's solution \\
\hline Diarrea & $\mathrm{Na}+, \mathrm{Cl}^{-}, \mathrm{HCO}_{3}^{-}, \mathrm{K}+, \mathrm{H}_{2} \mathrm{O}$ & $\begin{array}{c}\text { Hartmann's solution }+ \text { soda 2-3 } \\
\text { mmol/L }+\mathrm{KCl} 10-20 \text { mmol/L }\end{array}$ \\
\hline Bowel obstruction & $\begin{array}{c}\text { Mixed losses of a severe } \\
\text { degree }\end{array}$ & $\begin{array}{c}\text { Hartmann's solution + plasma to } \\
\text { relieve hypovolemic shock }\end{array}$ \\
\hline $\begin{array}{l}\text { Unclear etiology (in case } \\
\text { of unaccounted losses) }\end{array}$ & Unknown & $\begin{array}{c}\text { Multicomponent salt solutions } \\
\text { (Normofundin + 5\% glucose) }\end{array}$ \\
\hline $\begin{array}{l}\text { Uremia (rupture of the } \\
\text { bladder) }\end{array}$ & $\begin{array}{c}\text { Accumulation of metabolic } \\
\text { waste products, } \mathrm{K}+, \mathrm{H}+\end{array}$ & $\begin{array}{c}\text { Sol. } 0.9 \% \mathrm{NaCl} \text { or Normofundin }+ \\
5 \% \text { glucose + soda 2-3 mmol/kg }\end{array}$ \\
\hline
\end{tabular}


highly likely to develop side effects. Thus, in the postoperative period, it should be expected the appearance of symptoms of acute renal failure and various blood coagulation disorders (Shlapak et al., 2013).

For more effective redistribution of fluid from the interstitial space, Rheosorbilact solution might be administered as a part of infusion therapy. Hypertonic $\mathrm{NaCl}$ solution $(7.5-10 \%)$ can also be used, which in the case of intravenous administration also contributes to the quick transition of an intracellular fluid into the intracellular space. This results in a gentle but not long-lasting increase in the volume of fluid in the vascular bed. In this case, so-called low-volume infusion therapy is carried out. Maximum recommended doses for $7.5 \% \mathrm{NaCl}$ solution: $6 \mathrm{ml} / \mathrm{kg}$ for dogs and $4 \mathrm{ml} / \mathrm{kg}$ for cats.

The following approach is typical for current infusion therapy: if the program of infusion therapy is designed to administer a large volume of fluids, there must be a colloidal component in its composition. The ideal crystalloid/colloid ratio is $3: 1$. Thus, for each $100-150 \mathrm{ml}$ of crystalloids, 40 or $50 \mathrm{ml}$ of colloids should be infused depending on the clinical situation. Colloidal solutions must necessarily be included in the infusion program for patients with a blood level of total protein $\leq 35 \mathrm{~g} / \mathrm{L}$, albumin $\leq 20 \mathrm{~g} / \mathrm{L}$, anemia with hematocrit $\leq 20 \%$ or hemoglobin $\leq 70 \mathrm{~g} / \mathrm{L}$. Based on our practical experience, we recommend including in the program of infusion therapy, when guiding the animals with surgical pathology, dextran solutions (Polyglucin, Rheopolyglucin), hydroxyethyl starch (HES) (Refortan, Stabisol, Gecoton, Gecodez), and/or gelatin solution (Volutens, Gelofusine). The patient's condition should be monitored at the beginning of the infusion of these solutions, as they often have allergic reactions, in which case the infusion of this drug should be discontinued (Ko, 2019).
Intraoperative infusion therapy.

The main objectives of intraoperative infusion therapy are:

- elimination of fluid deficiency in diseased animal, which developed before the surgery;

- replenishment of physiological needs of the organism for fluid;

- replacement of pathological fluid losses that occur during the surgery.

Even if the patient is scheduled for planned surgery, he or she will have a certain fluid deficit before it begins. This is due to a 12-24 hour starvation diet before the operation. In addition, laxatives or enemas are often prescribed to prepare the intestine. These manipulations lead to loss of fluids and electrolytes, which is advisable to renew with balanced crystalloid solutions, e.g. Glykosteril F5, Normosol R, Sterofundin ISO, Plasma-Lyte, Hartmann (Battaglia \& Steele, 2021).

It should also be taken into account that surgical trauma leads to varying degrees of fluid loss in tissues and its sequestration. This deficit is manifested by a decrease in the fluid volume in the interstitial and intravascular space (Shlapak et al., 2013).

The estimated amount of fluid to be administered to patients to compensate for the deficit and loss during surgery is calculated according to the commonly accepted formulas of infusion therapy.

The determined needs are met according to the following infusion therapy regimen. During the first hour, $1 / 4-1 / 3$ of the volume of the balanced electrolyte solution is administered. After that, the infusion is administered at a rate of $5 \mathrm{ml} / \mathrm{kg} / \mathrm{h}$, increasing to $70 \mathrm{ml} / \mathrm{kg} / \mathrm{h}$ for severe surgical trauma. The goal is to maintain diuresis $>1 \mathrm{ml} / \mathrm{kg} / \mathrm{h}$. When administering infusion therapy, first of all, pay attention to the patient's condition and changes in physiological indicators (temperature, blood pressure, breathing, pulse, and heart rate, presence of nasal dis- 
charge, excitation, tremors, vomiting). If these signs occur, it is necessary to review the tactics and volume of infusion therapy in this patient. Sometimes it is better to administer a smaller volume of solutions rather than to deal with the consequences of excessive or rapid infusion (Butrov \& Galenko, 2008).

Particular situations occur when there is severe bleeding during surgical intervention.

Massive surgical blood loss accompanies long-termed surgical interventions and is a specific critical condition that develops very quickly and, in the pathogenesis of which, severe persistent hypovolemia, anemia and threatened coagulopathy combined with severe shock-induced sympathoadrenal stress and inflammatory mediator release as well as body cooling are dominating ( Gorobets et al., 2010).

These blood losses may occur during the surgical intervention and most often are associated with the complexity of the intervention. It is often necessary to take into account not only the need to remove the damaged organs within healthy tissues but also pathological angiogenesis that can lead to the severe vascularization of the surgical zone. Both of these factors can strongly influence the volume of blood loss (Gorobets et al., 2011).

However, several surgeries (especially large and unusual) are accompanied by massive blood loss, which requires an active infusion-transfusion therapy (ITT).

Traditionally, massive blood loss is a loss of more than $30 \%$ of total blood volume during 24 hours $(30 \mathrm{ml} / \mathrm{kg}$ in dogs and $20 \mathrm{ml} / \mathrm{kg}$ in cats).

Rapid blood loss of the same volume due to damage of a large vessel during surgery (with correct actions of the surgeon and anesthesiologist) is usually easier to tolerate than prolonged bleeding during a long-term traumatic intervention (Gorobets et al., 2011; Rozanski \& Rush, 2012).
The combination of hypotension, hypothermia, coagulopathy, and acidosis is a constant syndrome during the development of hemorrhagic shock, which maintains and strengthens the "vicious circle", and if it is not broken - the result will be unfavorable.

The basis of an effective ITT for high blood loss in the surgery:

- supporting sufficient preloading of the heart using intensive intravenous infusion;

- gradual manipulation with the composition of infusion with a focus on the volume of already lost and expected blood loss taking into account clinical characteristics and hematologic indices;

- timely use of cardiovasotonics (ephedrine, mesaton, noradrenaline, dopamine) for support of post- and preloading in cases of possible development of hemodynamic crisis and hypovolemic shock;

- prevention and treatment of hemostasis system disorders (Gorobets et al., 2011).

Eliminating the effects of massive blood loss, it should be borne in mind that bleeding occurs in a sick animal on the background of both the underlying disease and concomitant pathologies. Besides, the sick animal is put under anesthesia, which also affects its condition, and especially hemodynamics and compensatory reactions (Rozanski \& Rush, 2012).

In most cases, it is only possible to estimate approximately the volume of blood loss during the massive blood loss. It is more or less accurate if most of the spilled blood enters a vacuum aspirator or a cavity from which it has been removed in a measuring container. The weighing of napkins soaked in the blood helps to estimate blood loss.

Calculations of blood loss by the level of hematocrit, albumin, platelets, and 
red blood cells, all sorts of tables and devices are not accurate enough and require additional assistants, devices, and time.

In the intensive care of the massive blood loss, a major role is played by ITT phasing - the transition from the infusion of crystalloids and synthetic colloids to timely and reasonable transfusion of blood components (fresh frozen plasma, erythrocyte mass, whole blood, donor platelets) (Shlapak et al., 2013).

The principle of ITT phasing in case of ongoing bleeding allows the anesthesiologist to manage continuous intravenous infusion, maintaining the required circulating blood volume and not causing excessive hemodilution with loss of minimally acceptable coagulation potential and oxygen transport function of the blood (Gorobets, 2010).

Separately, it should be mentioned about urgent ITT for severe blood loss, which is characterized by quick loss of a large volume of the blood. In similar situations, the main task for the doctor who carries out ITT is to replenish the vascular bed as quickly and efficiently as possible (Table 2).

In 1944, the use of hypertonic $\mathrm{NaCl}$ solutions was suggested for the treatment of severe hemorrhagic shock. In 1980, I. Velasco has published experimental data on the improvement of the condition in dogs with simulated severe hemorrhagic shock.

Studies have shown that even at blood loss up to $50 \%$ of the circulating blood volume, infusion of $7.5 \%$ sodium chloride at a dose of $4 \mathrm{ml} / \mathrm{kg}$ is enough to restore cardiac output and regional blood flow (Galushko, 2011).

Bolus administration of $7.5 \%$ sodium chloride solution at a dose of $20-40 \mathrm{ml}$ was associated with increased arterial blood pressure, restoration of consciousness, and improvement of urine excretion, i.e. there were signs of shock reversibility that is confirmed by studies in human medicine (Butrov \& Galenko, 2008).
These works served as a basis for further research and the emergence of the concept of small-volume resuscitation as one of the methods of emergency therapy for different stages of shock and terminal conditions. This therapy is based on a rapid infusion of a small volume $(4 \mathrm{ml} / \mathrm{kg})$ of $7.2-7.5 \%$ sodium chloride and is associated with rapid mobilization of endogenous fluid into the vascular bed from the interstitium and intracellular space by the osmotic gradient. This solution in a volume of $250 \mathrm{ml}$ has the same volemic effect as 1 liter of 5\% albumin solution (Ko, 2019).

The hemodynamic effect of hypertonic solutions is very brief that is due to the rapid alignment of the osmotic gradient between the extracellular and intracellular sectors (Makintayr et al., 2012). The use of $5 \%$ glucose solution in the program of infusion therapy (renewal of circulating blood volume) is contraindicated.

To maintain the achieved increase in intravascular volume it was recommended to use hypertonic sodium chloride solution together with colloids (Shlapak et al., 2013). The obtained bicomponent solution, on the one hand, increases plasma osmolarity and mobilization of intracellular water (hypertonic component) and, on the other hand, it provides an increase in plasma oncotic pressure and preservation of intravascular volume (colloidal component) (Table 3).

Today it is believed that the most stable volemic effect is manifested when using a mixture of hypertonic $\mathrm{NaCl}$ solution with dextran or HES in a 1:1 ratio at a dose of 4-5 ml $/ \mathrm{kg}$ (Belyayev et al., 2004).

One of such combined multicomponent solutions is Gekoton. The main active substances of the drug are the third-generation of hydroxyethyl starch 130/0.4, xylitol, and sodium lactate.

Gekoton belongs to the group of multicomponent colloidal hyperosmolar 
solutions. Gekoton has hemodynamic, rheologic, anti-shock, and desintoxicating effects. After administration of the drug into the vein, the osmotic blood pressure is increased, the evacuation of fluid from tissues into the vascular bed is enhanced, impaired hemodynamics is restored, the microcirculation and blood rheological properties are enhanced, cardiac activity, the process of protein metabolism, desintoxicating function of the liver are increased in animals (Shlapak et al., 2013).

The maximum daily dose (in exceptional cases overdose is allowed) is $5-10 \mathrm{ml} / \mathrm{kg} /$ day.

Gelatin solutions are solutions that have a modified molecular structure. They are derived from denatured protein. This protein is extracted from the collagen tissue of cattle by thermal degradation, hydrolysis, and succinution. Gelatin drugs are isotonic, iso-oncotic (4-8\%) gelatin solutions and low molecular weight (20000-40000 Da) plasma substitutes. Their $\mathrm{pH}$ is $7.1-7.7$ and they create a colloid osmotic pressure of $33.3 \mathrm{mmHg}$ or $453 \mathrm{mmH}_{2} \mathrm{O}$, osmolarity $274 \mathrm{mosmol} / \mathrm{L}$, volume effect of these drugs is $40-100 \%$ (Pulnyashenko, 1997).

The meaning of blood dilution is in an effort to minimize the loss of formed elements at the stage of the surgery when blood volume loss is inevitable. If hemodilution does not cause clinically significant bleeding, it is possible to expect smaller losses of blood components (at the loss of equal volume) through low hematocrit. If the situation allows, it should

\section{The main colloidal solutions from the arsenal of veterinary and human} medicine that are used for the treatment of dogs and cats

\begin{tabular}{|c|c|c|c|c|c|c|}
\hline Solution & $\begin{array}{l}\text { Osmolarity, } \\
\text { Mosm/L }\end{array}$ & $\begin{array}{c}\text { Colloid } \\
\text { osmotic } \\
\text { pressure, } \\
\mathrm{mmHg}\end{array}$ & $\begin{array}{c}\text { Molecular } \\
\text { mass, } \\
\text { kDa }\end{array}$ & $\begin{array}{l}\text { Volemic } \\
\text { effect, \% }\end{array}$ & $\begin{array}{l}\text { Duration of } \\
\text { therapeutic } \\
\text { action, hour }\end{array}$ & $\mathrm{pH}$ \\
\hline \multicolumn{7}{|c|}{ Dextrans } \\
\hline $\begin{array}{l}10 \% \\
\text { Rheopolyglucin }\end{array}$ & 310.0 & 90 & $35-45$ & 200 & $3-4$ & $4.5-6.5$ \\
\hline $6 \%$ Polyglucin & 308.0 & - & $50-80$ & - & $4-6$ & $4.5-6.5$ \\
\hline \multicolumn{7}{|c|}{ Gelatins } \\
\hline $4 \%$ Gelofusine & 274.0 & 34 & 23 & 100 & $3-4$ & $7.1-7.7$ \\
\hline $4 \%$ Volutens & 274.0 & 34 & 30 & 100 & $3-4$ & 7.4 \\
\hline \multicolumn{7}{|c|}{ First-generation of HES } \\
\hline $6 \%$ Stabisol & 300.0 & 18 & 450 & 100 & $6-8$ & $4.0-7.0$ \\
\hline \multicolumn{7}{|c|}{ Second-generation of HES } \\
\hline $\begin{array}{l}\text { 6\% Refortan, } \\
6 \% \text { Gek- } \\
\text { Infusion }\end{array}$ & 300.0 & 28 & 200 & 100 & $4-6$ & $4.0-7.0$ \\
\hline $\begin{array}{l}10 \% \text { Refortan, } \\
10 \% \text { Gek- } \\
\text { Infusion }\end{array}$ & 300.0 & 65 & 200 & 130 & $4-6$ & $4.0-7.0$ \\
\hline \multicolumn{7}{|c|}{ Third-generation of HES } \\
\hline $6 \%$ Voluven & 308.0 & 36 & 130 & 100 & $4-6$ & $4.0-5.5$ \\
\hline Gecoton & 890.0 & - & 130 & 100 & $4-6$ & $5.5-7.5$ \\
\hline
\end{tabular}


be seek to restore red blood counts only after bleeding has stopped (Yin, 2008).

Fluid requirements during the postoperative period.

When calculating the level of infusion therapy for a sick animal in the postoperative period, several factors must be taken into account.

It is necessary to calculate the physiological needs of the animal, which is about $30 \mathrm{ml} / \mathrm{kg} /$ day for cats and $30-60 \mathrm{ml} / \mathrm{kg} /$ day for dogs. To this figure are added losses that are not perceived (through salivation, skin, and lungs): approximately $20 \mathrm{ml} / \mathrm{kg}$ / day and approximately the same amount is lost with fecal masses and urine. If a sick animal has a fever, it is necessary to add fluid in an amount of 4-8 ml/ $\mathrm{kg}$ per degree of total body temperature above normal physiological indicators (Rozanski \& Rush, 2012). Other losses (through probes, drains, etc.) are also taken into account.

Specific losses and fluid requirements (in cases of intestinal paresis, acute gastric dilatation with torsion, in case of loss into the third space after laparotomy and thoracotomy or massive tissue damage) should also be taken into account, during the first 24 hours after surgery it is necessary to give solutions at a level of about 4-15 ml/hour (100 $400 \mathrm{ml} /$ day), controlling indicators of the cardiovascular system and respiratory organs.

\section{Conclusions and future perspectives}

Before the planned surgery, the hemoglobin level should be within the range of $110-180 \mathrm{~g} / \mathrm{L}$ for dogs and $80-150 \mathrm{~g} / \mathrm{L}$ for cats, the hematocrit level should be not less than $37 \%$ for dogs and $26 \%$ for cats, and the albumin level should be not less than $25 \mathrm{~g} / \mathrm{L}$ for dogs and cats. Also, it should be taken into account the animal's general condition and the presence of possible concomitant diseases.
The following approach is characteristic for the current infusion therapy: the ideal crystalloid/colloid ratio is $3: 1$. Thus, for each $100-150 \mathrm{ml}$ of crystalloids, 40 or $50 \mathrm{ml}$ of colloids should be infused, depending on the clinical situation. Colloidal solutions must be included in the infusion program for patients with a blood level of total protein $\leq 35 \mathrm{~g} / \mathrm{L}$, albumin $\leq 20 \mathrm{~g} / \mathrm{L}$, anemia with hematocrit $\leq 20 \%$ or hemoglobin $\leq 70 \mathrm{~g} / \mathrm{L}$.

When calculating the level of infusion therapy for sick animals in the postoperative period, several factors must be taken into account: calculate the physiological requirement in the animal, which is about $30 \mathrm{ml} / \mathrm{kg} /$ day for cats and 30-60 ml/kg/day for dogs and specific losses and fluid requirements.

\section{References}

Battaglia, A. M., \& Steele, A. M. (2020). Small Animal Emergency and Critical Care for Veterinary Technicians-E-Book. Elsevier Health Sciences.

Belyayev, A. V., Bondar, M. V., \& Dubov, A. M. (2004). Rukovodstvo po intensivnoy terapii [Guide to Intensive Care]. Kyiv: Vishcha shkola.

Butrov, A. V., \& Galenko, S. V. (2008). Kombinirovannyye gipertonicheskiye rastvory $v$ intensivnoy terapii kriticheskikh sostoyaniy [Combined hypertonic solutions in intensive care of critical conditions]. Ukrainskyi zhurnal ekstremalnoi medytsyny imeni G. O. Mozhaeva, 9(4), 18-21.

Cherniy, V. I., Kolesnikov, A. N., Oleynikov, K. N., Yegorov, A. A., \& Biloshapka, V. I. (2012). Ratsional'naya infuzionnaya terapiya [Rational fluid therapy]. Donetsk: Izdatel

Zaslavskiy A. Yu.Detyu, F. (2009). Yzbrannye voprosy neotlozhnoy veterynarnoy pomoshchy sobakam y koshkam [Selected issues of emergency veterinary care for dogs and cats]. Tom 1. Royal Kanyn.

Galushko, O. A. (2011). History of infusion therapy: from William Harvey to the present day. Internal Medicine, 2, 56-60. 
Gorobets, Ye.S., Feoktistov, P.I., \& Borovkova, N. B. (2010). Volyuven — kolloidnyy plazmozamenitel' v lechenii massivnoy operatsionnoy krovopoteri pri onkologicheskikh operatsiyakh [Voluven is a colloidal plasma substitute in the treatment of massive surgical blood loss during oncological operations]. Ukrainskyi zhurnal ekstremalnoi medytsyny imeni G. O. Mozhaeva, 11(1), 74-81.

Gorobets, Ye. S., Zotov, A. V., \& Feoktistov, P. I. (2011). Infuzionnotransfuzionnaya terapiya massivnoy krovopoteri vo vremya khirurgicheskogo vmeshatel'stva [Infusion-transfusion therapy of massive blood loss during surgery]. Anesteziologiya i intensivnaya terapiya: 21 vzglyad na problemy XXI veka. Moskva: Binom.

Ko, J. (Ed.). (2019). Small animal anesthesia and pain management: a color handbook. CRC Press.

Makintayr, D. K., Drobats, K. Dzh., Khaskingz, S. S., \& Sakson, U. D. (2008). Skoraya pomoshch' i intensivnaya terapiya melkikh domashnikh zhivotnykh. Prakticheskoye rukovodstvo [Small animal ambulance and intensive care. A practical guide]. Akvarium.Pulnyashenko, P. R. (1997). Anesteziologiya i reanimatologiya sobak i koshek. Prakticheskoye posobiye [Anesthesiology and resuscitation of dogs and cats. Practical guide.], Kiyv: Fauna-servis.

Rozanski, E. A., \& Rush, J. E. (2012). Small Animal Emergency and Critical Care Medicine. Manson: Pub./Veterinary Press.

Shlapak, I. P., Netyazhenko, V. Z., \& Halushko, O. A. (2013). Infuziyna terapiya v praktytsi likarya vnutrishn'oyi medytsyny: Navchal'nyy posibnyk [Infusion therapy in the practice of internal medicine: A textbook]. Kyiv: Lohos.

Yin, A. (2008). Polnyy spravochnik po veterinarnoy meditsine melkikh domashnikh zhivotnykh. The Small Animal Veterinary Nerdbook [The Complete Guide to Small Animal Veterinary Medicine. The Small Animal Veterinary Nerdbook]. Sofiya, Akvarium-Print.

П. К. СОЛОНін, М. А. КУЛіда (2021). ІНФУЗІЙНА ТЕРАПІЯ В ПЕРИОПЕРАЦІЙНОМУ ПЕРІОДІ У СОБАК І КОТІВ. Ukrainian Journal of Veterinary Sciences, 12(1): 60-68, https://doi.org/10.31548/ujvs2021.01.007

Анотація. Сучасний підхід у лікуванні тварин із хірургічною патологією вимагає введення інсузійних розчинів упродовж всього периоперачійного періоду: до операчії (при екстрених втручаннях), під час операчії й після неї.

У тварин із хірургічними захворюваннями, які надходять на лікування, досить часто спостерігаються різного ступеня порушення водно-електролітного балансу. Причиною цих порушень є, як сама хірургічна патологія (наприклад, перитоніт, кишкова непрохідність), так і наявна в пацієнта супутня патологія (ниркова недостатність, иукровий діабет, серцева недостатність тощо). Від правильного оцінювання і корекції иих порушень багато в чому залежить успіх здійснюваного оперативного лікування.

у статті представлено сучасні підходи до проблем проведення інфрузійної терапії у ветеринарній хірургії собак і котів.

Велику увагу приділено вибору засобів для інфрузійної підтримки тварин у периопераційному періоді. Наведено приклади визначення об'єму розчинів для інфузії під час передопераційної підготовки, інтенсивної терапії масивної інтраопераційної крововтрати й післяопераційного ведення пацієнтів.

Ключові слова: периоперачійний період, інфузійна терапія, крововтрата, кристалоїди, колоїди, інфузійні розчини 